\title{
Implementation of Good Governance Ombudsman Recommendations
}

\author{
Iga Sukma Devi ${ }^{1 *}$, F.C. Susila Adiyanta, Nabitatus Sa'adah \\ \{iga.sukma.dewi@gmail.com ${ }^{1}$ s susila.adiyanta@gmail.com² ${ }^{2}$, nabitatass@gmail.com*3
}

Fakultas Hukum, Universitas Diponegoro, Jl. Prof. H. Soedarto, S.H., Semarang, Indonesia $50275^{1}$

\begin{abstract}
Ombudsman Republik Indonesia (ORI) is an institution authorized to supervise the performance of public service that cannot prosecute or impose sanctions on the reported institution, but it can recommend the institution to conduct self-correction. The nature of Ombudsman's recommendation is not binding and cannot be forced to execute. This causes the recommendation is often being ignored by the state administrators. This paper was written using the qualitative approch with empirical juridical approach. Based on the result, it can be concluded that the implementation of Ombudsman's recommendation has not been effective yet since it takes a long time, like what had happened in Central Java. The juridical consequence when the state administrators do not implement the commendation is that they can be given administrative and criminal sanctions. Administrative sanctions are for the reported and the boss, meanwhile the criminal ones are for anybody who inhibits Ombudsman on implementing investigation. Sanctions giving for the state administrators who do not implement the Ombudsman's recommendation is regulated in Article Pasal 38 and 39 Constitution No 37 of 2008, Article 36 Constitution No 25 of 2009 about Public Service, Article 351 Constitution No 23 of 2014 about Local Government, Article 36 Government Regulation No 12 of 2017 about the Coaching and Supervising of the Local Government Organization.
\end{abstract}

Keywords: Supervisory Institution, State Auxiliary Organ, and Ombudsman Recommendation

\section{Introduction}

\subsection{Background}

The event of the Proclamation of Indonesian Independence on August 17, 1945, was not only a moment of Indonesian independence but at the same time became the moment of the initiation of Indonesia as the rule of law. Regarding the principle of the rule of law adopted by Indonesia according to Soeprapto is "the legal state of the board (verzorgingstaat).[1] When examined the concept of the rule of law adopted by the State of Indonesia, it is more directed to the concept of welfare-state or commonly called the welfare state where the state is obliged to realize public welfare. This means that the state must intervene in people's lives as a step for people's welfare.

The concept of welfare-state itself can be found in the Preamble of the Constitution of the Republic of Indonesia 1945 paragraph IV which reads: 
"The state protects the nation and all spilled Indonesian blood, promotes public welfare, educates the life of the nation, and participates in carrying out world order based on independence, eternal peace, and social justice."

In order to carry out the objectives of the state in terms of "general welfare," the state has taken various measures so that welfare can be realized. One of which is by providing services from the government to the community. This is also explained in the General Explanation of Law Number 25 Year 2009 regarding Public Services, stating that the state is obliged to meet the needs of every citizen through a government system that supports the creation of excellent public services in order to meet the basic needs and civil rights of every citizen on public goods, public services and administrative services.

Nowadays, the implementation of public services is still faced with conditions that are not yet in accordance with the needs and changes in various fields of life of the people, nation and state. This happens because there is no readiness to respond to changes in social values in society. Meanwhile, the new order of the Indonesian people is faced with global challenges triggered by advances in science, information, communication, transportation and trade.[2]

Providing quality public services is highly expected by the people of Indonesia. In reality, the implementation of public services are still often colored by the practice of administrative malls, including corruption, collusion, and nepotism.[3] This can lead to material and immaterial losses for the community or individuals. Although public services are still far from expectation, the government is trying to optimize services to the community. Regarding public services, supervision is one way to build and maintain the legitimacy of citizens towards government performance by creating an effective system of supervision, both internal supervision (internal control) and external control (external control) in addition to encouraging community supervision (social control).[4]

The Ombudsman of the Republic of Indonesia (ORI), according to the provisions of Article 1 number 1 of Law Number 37 of 2008, is a state institution that has the authority to oversee the administration of public services, both carried out by state and government administrators.[5] These include State-Owned Enterprises, Agencies Regional-owned Enterprises, and State-Owned Legal Entities, as well as private or individual entities given the task of providing certain public services that part or all of the funds are sourced from the state budget and/or regional budget. The Ombudsman is an external oversight body whose existence is expected to control the duties of state and government administrators in the administration of public services.[2] This institution works based on community complaints. In this case, the community has the right to file a complaint if the rights of the community feel disadvantaged by the state administrator. The Ombudsman is an independent institution carrying out its duties and authority is free from interference from other powers.

The role of the Indonesian Ombudsman is to supervise public services by state administrators, including State-Owned Enterprises or Regional-Owned Enterprises, judiciary, National Land Agency, Police, Attorney, Regional Government, Ministries, Non-Ministry Agencies, State Universities, National Army Indonesia, and so on. The Ombudsman in exercising its authority does not have the authority to demand or impose sanctions on the reported institutions, but instead provide "recommendations" to the agencies to conduct selfcorrection. Understanding Recommendations according to Law Number 37 of 2008 are conclusions, opinions and suggestions prepared based on the results of the Ombudsman investigation, to the Reported Party's superiors to be carried out and/or acted upon in order to improve the quality of good government administration. The nature of the Ombudsman's recommendation is non-binding and cannot be forced to be executed [6]. 
This has resulted in Ombudsman's recommendations being often ignored by state administrators. One example is related to the implementation of the Ombudsman recommendations issued to the Semarang City Government, where the contents of the Ombudsman recommendations are efforts to control and demolish the BTS tower buildings of PT. Linggajati Al Munshurin which is not licensed (does not have a building permit). This case occurred around 2012, but the demolition of the new tower was carried out in 2018. [7] Another example is the recommendation of the Ombudsman to the Mayor of Yogyakarta related to mal-administration in the process of handling reports of violations of disturbances permits by the Yogyakarta City Government Licensing Service In this case, the Ombudsman recommendations are only implemented partially and are now final.[8] The two events above illustrate the strength of the Ombudsman's recommendations that are not binding or non-legal binding.

Based on the above problems, research will be carried out for the writing of the law entitled "Implementation of Good Governance Ombudsman Recommendations (Research Study at Ombudsman Representative Offices in Central Java and Yogyakarta)."

\subsection{Problem Formulation}

1. How is the Ombudsman's recommendations implemented by state administrators in the Central Java Province and Yogyakarta Special Region?

2. What are the juridical consequences for rejecting the implementation of the Ombudsman recommendations by state administrators?

\subsection{Research Objectives}

Based on the above problem formulation, the objectives expected from this research are as follows:

1. To find out and review the implementation of the Ombudsman recommendations by state administrators in the area of Central Java Province and Yogyakarta Special Region.

2. To find out and assess the juridical consequences of the rejection of the implementation of the Ombudsman recommendations by state administrators.

\section{Research Methods}

\subsection{Approach Method}

The writing of this law uses the empirical juridical approach, an approach that is done by looking at the reality that exists in practice in the field. Also, this price used to find the answers of problem formulations that are sought through field research.

\subsection{Research Specifications}

The research specifications used are descriptive analytical, which is intended to obtain an explanation or description as it is in accordance with empirical facts obtained from research in the field. 


\subsection{Types and Sources of Data}

Types and sources of data used in writing this law use primary data. The primary data is data obtained directly from observations in the field and from interviews and secondary data are data sourced from library research.

\subsection{Data Collection Methods}

The method used for the collection of legal materials required in writing this paper was obtained by conducting field research, the acquisition of legal material through field research carried out by collecting data and information directly, through in-depth interviews with key informants. The key informants for this legal writing are divided into three research subjects, namely from the Ombudsman, the reported party (Satpol PP Semarang City), and the reporting party (community or individual). The fieldwork was carried out in the Central Java Ombudsman Representative Office, Yogyakarta Special Region Ombudsman Representative Office, Semarang City Satpol PP Office, Ngaliyan District Semarang City, and Gedong Tengen District Yogyakarta. Library research (library research) the acquisition of legal materials through library studies collected by searching and studying and understanding scientific books that contain the opinions of several scholars. In addition, legislation that is closely related to the writing of this law was also collected. The legal materials collected are then subjected to the editing of legal materials, the classification of relevant legal materials and systematic breakdown.

\subsection{Data Analysis Method}

Data analysis method used in this research is qualitative analysis. Qualitative analysis is done by describing and describing data and facts generated from a field study with a way of thinking based on general facts followed by the creation of a summary that is specific to submit suggestions.[9]

\section{Results and Discussion}

\subsection{Implementation of the Ombudsman Recommendation by State Organizers in the Regions of Central Java Province and Yogyakarta Special Region as an Implementation of the Principles of Good Governance}

\subsubsection{Independent Ombudsman Institution as Supervisor of Public Services}

a. General description of Ombudsman Representatives in the Regions as Representatives of the Ombudsman of the Republic of Indonesia

The establishment of an Ombudsman representative is one of the implementations of Article 5 and Article 43 of Law Number 37 Year 2008 concerning the National Ombudsman of the Republic of Indonesia. The Ombudsman Representative has a strategic position in helping the community to obtain services from the Ombudsman of the Republic of Indonesia. The establishment of an Ombudsman representative for the Ombudsman of the Republic of Indonesia, functions to facilitate the implementation of functions, duties and authority to all 
regions of the country of Indonesia because the Ombudsman representative is a stewardship, and has a hierarchical relationship with the Ombudsman of the Republic of Indonesia.[10]

General Explanation of the Government Regulation of the Republic of Indonesia Number 21 of 2011 concerning the Establishment, Composition and Working Procedure of Representative Ombudsman of the Republic of Indonesia states that the formation of Ombudsman representatives is based on community needs, availability of resources, effectiveness, efficiency, complexity, and workload.[11] The formation of Ombudsman representatives is not necessarily carried out in all provinces or districts/cities, but it is based on community needs. The community needs in this Government Regulation are not only interpreted as coming from the community, but also coming from the reconsiderations of the Ombudsman of the Republic of Indonesia conducted by the Ombudsman of the Republic of Indonesia. For example, the community needs a supervisory institution to create a clean government and quality public service delivery. This is the consideration of the Ombudsman of the Republic of Indonesia to establish an Ombudsman representative.

Ombudsman representatives have duties, functions and authorities that are "mutatis mutandis" with the Ombudsman of the Republic of Indonesia.[12] Mutatis mutandis in this case means that the provisions concerning the functions, duties and authority of the Ombudsman that apply to the Ombudsman also apply to the Representative of the Ombudsman by making changes as necessary. The duties, functions and authorities of the Ombudsman representatives are regulated in the provisions of Article 6 and Article 7 of the Government Regulation of the Republic of Indonesia Number 21 of 2011 concerning the Establishment, Composition and Working Procedure of the Representative Ombudsman of the Republic of Indonesia. Representatives of the Ombudsman in the regions are led by a Head of Assistant who is responsible for the Ombudsman of the Republic of Indonesia through the Chief Representative. The tasks assigned to each assistantship aim to realize quality public services, as well as good and clean governance. In addition, representatives of the Ombudsman also have a hierarchical relationship with the Ombudsman of the Republic of Indonesia in carrying out his authority.

\section{b. Legal Basis for the Authority of the Ombudsman in Providing Recommendations to the Government for Public Services}

The establishment of a state auxiliary organ in Indonesia is carried out according to different legal basis, some are based on the 1945 Constitution, including the General Election Commission, and some are based on the law including the Indonesian Broadcasting Commission and the Consumer Protection Agency, and based on the Presidential Decree including the Commission National Ombudsman.[13]

Denny Indrayana divides state auxiliary organs into 2 (two) types, namely independent regulatory bodies and executive brunch agencies. The type of independent regulatory bodies refers to institutions that are independent and are not included in any branch of power. Examples of independent regulatory bodies include the Judicial Commission (KY), the Ombudsman of the Republic of Indonesia (ORI), the Corruption Eradication Commission (KPK) and the Indonesian Child Protection Commission (KPAI). The type of executive brunch agencies refers to state institutions that are under executive power. This institution has the main duties and functions to help carry out executive functions, namely carrying out the mandate of the law. The executive body consists of the President, Vice President and ministers.[14]

The establishment of a state auxiliary organ aims to carry out its duties and function optimally as a solution to the limited capabilities of primary state institutions, in addition to 
that the tasks and functions of the state auxiliary organ must be adjusted to the goals of the state. The Ombudsman of the Republic of Indonesia, when viewed in terms of its function, is not a primary or primary institution whose authority is clearly stated in the Constitution of the Republic of Indonesia, instead, it is an auxiliary state institution established for the bureaucratic reform aspired to as the initial goal of the state.

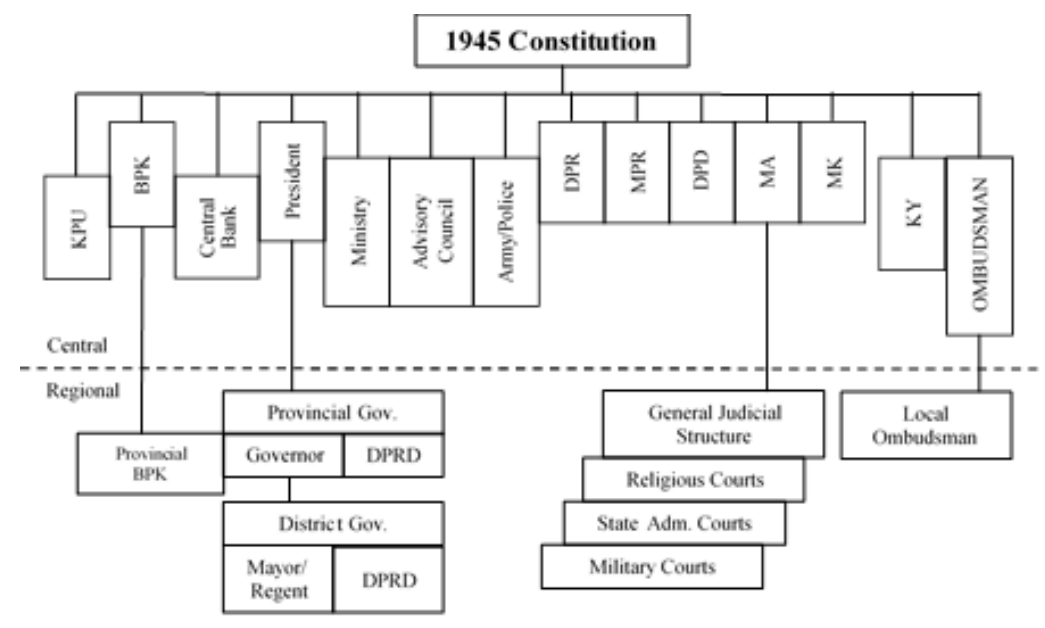

Figure 1. The existence of the Indonesian Ombudsman in Indonesian State Administration

Based on the picture, it can be seen that the Ombudsman institution is not a main state institution that is clearly stated in the constitution, but it is a state auxiliary organ whose formation is based on the Presidential Decree. In its development the Ombudsman continues to strive to optimize performance. One of which is by designing the right flow and implementation mechanism by simplifying the bureaucracy. Following is the flow of report or complaint settlement by the Republic of Indonesia Ombudsman: 


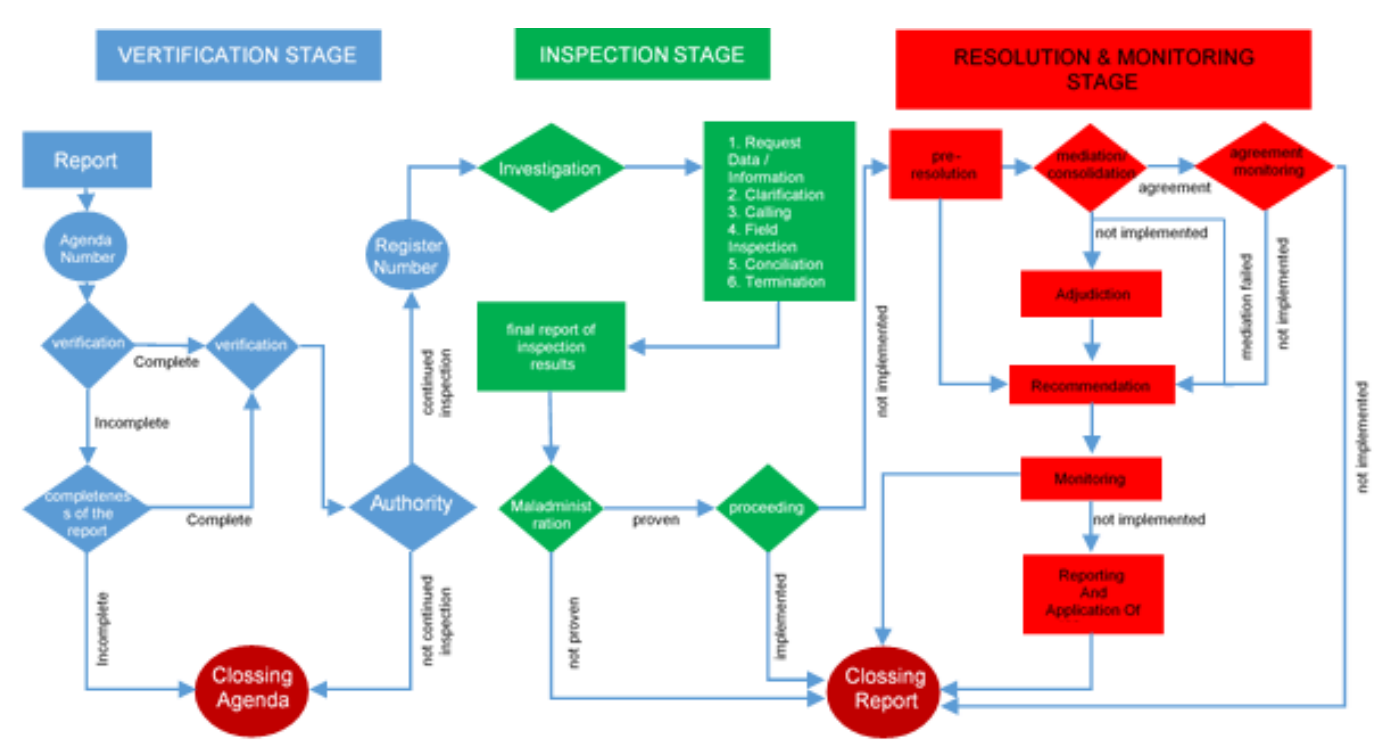

Figure 2. Flow chart of the RI Ombudsman Report

Every citizen and resident, whether living in the territory of the Republic of Indonesia or not, has the right to submit a report to the Ombudsman. Reports submitted to the Ombudsman or Ombudsman representatives regarding acts of deviation that result in poor quality of public services. Reports can be submitted by signing the Ombudsman's office to enable his complaints verbally and in consultation with the assistant Ombudsman. Reports can also be submitted in writing in the form of a letter addressed to the office of the Ombudsman or the representative of the Ombudsman, explaining the chronology of the problem using proper and correct Indonesian. Another way that can be done by the public in submitting reports is by facsimile, telephone, and e-mail as stipulated in Law Number 37 Year 2008. The Ombudsman in practice always encourages the public to submit reports in writing for formal administrative completeness.[12]

Reports that meet formal requirements are then registered and submitted to the head of the Ombudsman to determine the assistant in charge. The Assistant Ombudsman will conduct a substantive selection to find out more whether the report includes the authority of the Ombudsman or not. Reports that are not within the authority of the Ombudsman, the assistant drafts a letter to the reporter to explain that the report reported is not the authority of the Ombudsman.[12]

The draft of a letter made by a young assistant will be examined by a senior assistant who is then conveyed to the chairman of the Ombudsman to request authorization. If the report is the authority of the Ombudsman but is deemed to require further data, the assistant ombudsman will ask the reporter to complete the report. Reports whose substance is the authority of the Ombudsman, the assistant Ombudsman and members of the Ombudsman appointed as supervisors for handling the report will examine more deeply the substance of the report in question, including planning field investigation activities if necessary. The Ombudsman's Assistant will submit a request for clarification or make recommendations 
which will then be sent to the reported party after receiving approval from the Ombudsman Chair.[12]

Requests for clarification of the Ombudsman which get a response from the reporter, , the Assistant Ombudsman who handles the report will learn whether the reporter has given an answer in accordance with the provisions of the applicable legislation. The Ombudsman send a reply the second time to the reported to get further clarity. The Ombudsman immediately send a second clarification if within the specified time period, the reporter has not yet responded.[12]

Reported parties who do not provide responses to the clarification of the Ombudsman are deemed not using the right to answer. Based on the existing authority according to the law, the Ombudsman can issue recommendations that must be implemented by the reported and/or reported superior. If this is also not corrected by the reported party, then the Ombudsman can take the mechanism of delivering the results of investigations regarding the poor service of certain agencies to the media and provide special reports to the President and the House of Representatives to receive follow-up.[12]

c. Implementation of the Ombudsman Recommendation by State Organizers in Central Java and Yogyakarta Special Region

The Ombudsman of the Republic of Indonesia receives a report/complaint from one of the residents having the address at Perum BPI K-7 RT, 004/RW 010 Purwoyoso, Ngaliyan, Semarang, Central Java. The report contained complaints about the actions of the Semarang City Satpol PP for neglecting the legal obligation to control and demolish the construction of BTS towers by PT. Linggajati Al Munshurin which is not licensed (no IMB) and causes interference for residents of Jatisari Taliasih, Mijen, Semarang City.[12]

The reporter is the owner of the land that borders the Tower BTS owned by PT. Linggajati Al Munshurin, some of whom have stood buildings. The ownership of the land has been strengthened by the certificate of ownership rights/HGB. According to the reporter, the construction of the BTS (Base Transceiver Station) tower by PT. Linggajati Al Munshurin began in May 2011, the construction of the construction was without an IMB and socialization had been carried out but only attended by community representatives. The rejection of the residents was done by sending a letter of complaint to the Mayor of Semarang with copies of relevant agencies, so that the BPPT (Agency for Assessment and Application of Technology) did not give permission because the tower owner did not have a principle permit.

According to a recommendation from the City Planning and Housing Office of Semarang City on December 19, 2011 the Semarang City Civil Service Police Unit temporarily suspended the operation of the tower, but due to sealing damage, on February 25, 2012 the City Police Unit was resealing. The City of Semarang City Planning and Housing Office on 4 April 2012 issued a demolition recommendation on 14 May 2012 Satpol PP had made a memorandum of demolition and was sent to the Mayor of Semarang, but until the reporter submitted his report to the Indonesian Ombudsman Representative DIY-Central Java continue as it should. The reporter hopes that the Mayor of Semarang can act decisively and fairly in resolving these problems in accordance with the existing provisions.

Based on the description of the problem above, the follow up from the Ombudsman of the Republic of Indonesia is to follow up on the report through the Ombudsman Representative of DIY-Central Java asking for clarification from relevant officials in the Semarang City Government and the Reporting Party. The clarification of the Semarang City Satpol PP are as follows:[15] 
1. Regarding the lack of control over demolition of BTS (Base Transceiver Station) towers owned by PT. Linggarjati Al Manshurin which is unlicensed, Semarang City Satpol PP was concerning more on another issue; and therefore it was neglected.

2. According to the Semarang City Satpol PP, the construction of telecommunications towers and their buildings and equipment are owned by PT. Linggajati Al Munshurin and the BTS (Base Transceiver Station) tower will be used for shared towers, but do not know which cellular operators will use the BTS tower.

3. Another reason Semarang City Satpol PP has not made a demolition effort because there are technical constraints of demolition equipment and insufficient budget of dismantling a tower with a height of $72 \mathrm{~m}$

4. According to Semarang City Satpol PP, they have terminated the electricity and sealing the tower of the tower building that has been standing, until now this tower is no longer in operation.

5. According to the City Planning and Housing Office of Semarang City, since the beginning of the BTS (Base Transceiver Station) tower, it was built and there is no IMB. Semarang City Government through the Semarang City Planning Office has tried to take action by giving a warning/reprimand to PT. Linggajati tower owners 4 (four) times but have never responded.

6. On April 4, 2012 the Semarang City Urban Planning and Housing Agency also issued a recommendation letter to demolish the tower building, but there has been no follow-up from Satpol PP.

7. Semarang City Urban Planning and Housing Agency has yet to issue a new permit submitted by PT. Linggajati Al Munshurin, because it is still in dispute with local residents and asked to be resolved first.

Clarification regarding this issue is also made to the reporter or the public. Based on information from residents related to the construction of PT. Linggajati Al Munshurin, residents strongly reject the construction due to safety reasons.[16] This case entered the Ombudsman of the Republic of Indonesia and published Recommendation No.009/REK /0084.2012/PBP.02/VII/2013 based on the recommendation the Ombudsman believes that:

a. The efforts of the Semarang City Government to protect and attract investors into Semarang should be carried out by the government and the community. Nevertheless, these efforts should be carried out while respecting and obeying the applicable laws and regulations.

b. The neglect of the Semarang City Government in law enforcement (Perda) should not be allowed to happen as it is a form of legal disobedience in carrying out its duties and functions as a government apparatus.

c. Application for demolition of BTS tower owned by PT. Linggajati Al Munshurin should have been followed up as it should be given the construction of the BTS tower had violated existing legal provisions (there was no IMB permit and Nuisance Permit).

d. The actions of the Head of the Semarang City Satpol PP did not carry out demolition recommendations did not reflect the dedication and loyalty of subordinates to the leadership in enforcing the applicable laws and regulations. of:

The Indonesian Ombudsman issues recommendations related to these issues in the form 
a. Take decisive steps to demolish PT. Linggajati Al Munshurin, which was built without a permit, no later than 2 (two) weeks from the date of receipt of this recommendation.

b. Notifying the related staff (Satpol PP) to monitor and coordinate the implementation of the tower demolition.

Based on the chronology of the above problems, if analyzed using the perspective of State Administrative Law, the above case found an alleged maladministration, in the form of:

a. The state organizer (Semarang City Satpol PP) "neglected its obligation" to control and demolish the construction of a BTS (Base Transceiver Station) tower by PT. Linggajati Al-Munshurin which is not licensed (no IMB).

b. Tower construction which was established by PT. Linggajati Al-Munshurin is in violation of the applicable legal provisions because the tower does not yet have a nuisance permit and permission to build buildings, so it can be said that the construction of a BTS (Base Transceiver Station) tower is illegal.

Meanwhile, the case of publishing recommendations in DIY began when there was a report/complaint from one of the residents of Sosromenduran Gedongtengen Yogyakarta who felt disturbed by the operation of a restaurant (cafe) in the area. Residents are disrupted because of the operation of the restaurant (cafe) takes place at night and there is often live music activities while the restaurant (cafe) does not have a soundproof room.[17] Noise reporting was filed since October 2013, until the peak of the Indonesian Ombudsman issued binding recommendations for the Mayor of Yogyakarta. The reason for the issuance of the recommendation was because since 2013 the Yogyakarta City Government was considered not serious in overcoming the problem of restaurants (cafes) as well as the negligence of the Licensing Service that it did not provide proper service to the reporter.[10]

The DIY Ombudsman said the recommendation from the center was issued after it had previously made various clarification efforts with related parties including the reporter and also reported in this case the Office of Order, the Office of Investment and Licensing of the City of Yogyakarta. The Reported Party in this case was considered not serious and allowed them to leave the restaurant (cafe) still in operation today. One of the steps taken by the Ombudsman in the recommendation, the Ombudsman asks the Mayor of Yogyakarta to issue a third warning letter for Oxen Free restaurants (cafes) which have been proven to abuse licenses and noise.

Based on the results of monitoring the Ombudsman's recommendations have been carried out, but another problem in this case around 2017 the issuance of Permendagri policy No. 19 of 2017 concerning Revocation of Regulation of the Minister of Home Affairs Number 27 of 2009 concerning Guidelines for Determination of Disturbance Permit in the regions as amended by Ministerial Regulation In Republic of Indonesia Number 22 Year 2016 concerning Amendment to the Minister of Home Affairs Regulation Number 27 of 2009 concerning Guidelines for Determination of Disturbance Licenses in Regions." [10]

Based on the above case, if analyzed using the Perspective of State Administrative Law, namely the discovery of alleged maladministration in the form of:

a. Negligence from the Office of Discipline for not providing appropriate services to the reporter (community), in this case the City Government of Yogyakarta has not been responding for a long time and there has been no follow-up for a long time, while the restaurant activities (cafes) continue to run. This is increasingly disturbing residents. 
b. Misuse of interference and noise permits carried out by restaurants (cafes) are characterized by the existence, operations of these restaurants (cafes) at night and often there is live music activities while restaurants (cafes) do not have soundproof rooms. This is the reason for local residents submitting reports/complaints to the DIY representative Ombudsman.

The two cases above have similarities when viewed from the perspective of State Administrative Law, namely the discovery of alleged administrative malls. Regarding the implementation of the Ombudsman recommendations in Central Java based on the previous discussion, it was known that the issuance of the Ombudsman recommendations was carried out in 2013 but the implementation of the new recommendations was carried out in 2018. The length of time spent on implementing the Ombudsman recommendations shows that the implementation of the Ombudsman recommendations which in this case was "dismantling the tower The BTS (Base Transceiver Station) "does not necessarily only carry out the recommendations of the Ombudsman, the" demolition of the BTS (Base Transceiver Station) tower "can occur due to a new policy.

\subsection{Juridical Consequences for Rejection of the Implementation of the Ombudsman Recommendation by State Administrators}

The implementation of Law Number 37 of 2008 concerning the Ombudsman of the Republic of Indonesia and Law Number 25 of 2009 concerning Public Services is one of the innovations in the field of the legal system in Indonesia.[18] One of them is by providing Ombudsman recommendations to state officials or administrators who deviate from alleged mal-administration. One of the efforts to enforce the recommendations of the Ombudsman according to the Explanation of Law Number 37 of 2008 is to provide administrative sanctions and criminal sanctions. Administrative sanctions are imposed on reported parties and reported superiors who do not carry out the recommendations of the Ombudsman, while criminal sanctions are imposed on anyone who blocks the Ombudsman from conducting an examination. The purpose of obstructing the Ombudsman in conducting audits according to Article 44 of Law Number 37 of 2007 is when the Ombudsman in conducting examinations, such as summons to reported parties, witnesses, experts and/or translators for questioning, requesting an explanation to the reported, and at the time of carrying out field inspections was deterred. So those who get in the way can be subjected to criminal sanctions in the form of imprisonment for 2 (two) years or a maximum fine of IDR. 1.000.000.000,00 (one billion).[19] The above method is one way to reinforce the legal force of the Ombudsman's recommendations with the aim of creating justice for the people of Indonesia.

Administrative sanctions for state administrators who do not implement the recommendations of the Ombudsman are regulated in the provisions of Article 38 and 39 of Law Number 37 of 2008, Article 36 of Law Number 25 of 2009 concerning Public Services, Article 351 of Law Number 23 of 2014 concerning Regional Government,[20] Article 36 Government Regulation of the Republic of Indonesia Number 12 of 2017 concerning Development and Supervision of the Implementation of Regional Government.[21]

This also shows the strength of the recommendations of the Ombudsman although the recommendations of the Ombudsman are not legally binding. However, if the state administrators do not carry out the recommendations of the Ombudsman, administrative sanctions can be subject to compliance with applicable laws and regulations. The administration sanctions are intended for the Reported Party and the Reported Party's 
superiors who do not implement the Ombudsman's recommendation. This is in accordance with Article 39 of the Ombudsman Law, the Law on Public Services and the Law on Regional Governments. Reported parties or superiors of Reported parties who do not implement recommendations, in addition to being given administrative sanctions will also be published and reported to the Parliament and the President. The sanctions are based on the results of monitoring the Ombudsman first.

\section{Conclusion}

\subsection{Conclusion}

Based on the results of research and discussion in the previous chapter, it can be concluded that:

a. The implementation of the Ombudsman recommendations in Central Java Province and Yogyakarta Special Region has not been effectively implemented, because it takes a long time to implement the Ombudsman recommendations as happened in Central Java Province. Based on the previous discussion, the issuance of the Ombudsman recommendations was carried out in 2013 but the implementation of the new recommendations was carried out in 2018. This shows that the implementation of the Ombudsman recommendations in case of "dismantling the BTS (Base Transceiver Station) tower" does not necessarily only carry out the recommendations Ombudsman, the implementation of the "demolition of BTS (Base Transceiver Station) towers" can occur because there is a new policy.

b. Juridical consequences for rejecting the recommendations of the Ombudsman by State officials may be subjected to administrative sanctions and criminal sanctions. Administrative sanctions are imposed on reported parties and reported superiors who do not implement the Ombudsman's recommendations; while, criminal sanctions are imposed on anyone who blocks the Ombudsman from conducting an examination. Administrative sanctions for state administrators who do not implement the recommendations of the Ombudsman are regulated in the provisions of Article 38 and 39 of Law Number 37 of 2008, Article 36 of Law Number 25 of 2009 concerning Public Services, Article 351 of Law Number 23 of 2014 concerning Government Regions, Article 36 Government Regulation of the Republic of Indonesia Number 12 of 2017 concerning Development and Supervision of the Implementation of Regional Government.

\subsection{Suggestion}

Based on these problems, some suggestions can be submitted as follows:

a. There should have a support of actions from the State administrators so that the implementation of the Ombudsman's recommendations can be carried out effectively. The supports of action from state administrators is needed because the implementation of the Ombudsman's recommendations depends on the moral awareness of the state administration.

b. Creating quality public services as desired by the Ombudsman Law and the Public Service Act by accepting, accommodating and implementing Ombudsman recommendations so that good governance can be realized. 


\section{References}

[1] A. H. S. Soeprapto, M. F. I., and Attamimi, Ilmu Perundang-undangan: Dasar-dasar dan pembentukannya. Yogyakrta: Kanisius, 1998.

[2] S. Solechan, "Memahami Peran Ombudsman Sebagai Badan Pengawas Penyelenggaraan Pelayanan Publik di Indonesia," Adm. Law Gov. J., vol. 1, no. 1, pp. 67-89, 2018.

[3] and C. M. Pramukti, A. S., Pengawasan Hukum Terhadap Aparatur Negara. Yogyakarta: Pustaka Yustisia, 2016.

[4] Sujatmo, Beberapa Pengertian di Bidang Pengawasan. Jakarta: Balai Pustaka, 1986.

[5] Law Number 37 of 2008 concerning the Ombudsman of the Republic of Indonesia. .

[6] G. Asmara, Hukum Kelembagaan Negara: Kedudukan Ombudsman dalam Sistem Ketatanegaraan Republik Indonesia. Yogyakarta: LaksBang Pressindo, 2016.

[7] Pre-Research Results with M. Azet Azhar (Primary Assistant, Member of the Report Examination Assistance Team), January 24, 2019 at 15:51 PM, at the Central Java Ombudsman Representative Office. .

[8] Ombudsman Republik Indonesia, Laporan Tahun 2017 Ombudsman Republik Indonesia. Jakarta: Ombudsman Republik Indonesia, 2018.

[9] R. H. Soemitro, Metodologi Penelitian Hukum. Jakarta: Ghalia Indonesia, 1983.

[10] Interview with Nugroho Andriyanto (Head of Report Inspection Assistant), 25 February 2019 at 11:00 WIB, at the Ombudsman Representative Office of the Special Region of Yogyakarta. .

[11] Government Regulation of the Republic of Indonesia 21 of 2011 concerning Formation, Composition and Working Procedure of Representative Representatives of the Ombudsman of the Republic of Indonesia in Regions. .

[12] Interview with M. Amhar Azet (Primary Assistant, Member of the Report Examination Assistance Team), January 24, 2019 at 15:51 WIB, at the Central Java Ombudsman Representative Office. .

[13] T. T. Triwulan, Konstruksi Hukum Tata Negara Indonesia Pasca Amandemen UUD 1945. Jakarta: Kencana Prenada Media Group, 2010.

[14] D. Indrayana, Negara Antara Ada dan Tiada: Reformasi Hukum Ketatanegaraan. Jakarta: Kompas Media Nusantara, 2008.

[15] Interview with Marthin (Chair of the Regional Legislation), March 15, 2019 at 08:00 WIB, at the Semarang City Police Office. .

[16] Personal interview with a resident of Perum BPI Ngaliyan, Semarang, Central Java, on January 26, 2019, at 11:00. .

[17] Personal interview with Setiawan (Reporter), 15 March 2019 At 13:00 (located in Sosromenduran, Gedong Tengen Yogyakarta). .

[18] Law Number 25 of 2009 concerning Public Services. . 
[19] Article 44 of Law Number 37 of 2007. .

[20] Law Number 23 of 2014 concerning Regional Government. .

[21] Government Regulation of the Republic of Indonesia Number 12 of 2017 concerning Development and Supervision of Regional Government Administration. . 